\title{
MENCARI FORMAT HUKUM ISLAM YANG PROGRESIF BERKEARIFAN LOKAL: PENDEKATAN SOCIO-CULTURAL DAN MAQASHID AL SYARIAH
}

\author{
Fathurrahman Djamil \\ Fakultas Syari'ah dan Hukum UIN Syarif Hidayatullah Jakarta \\ Jln. Ir. H. Juanda No 95 Ciputat Tanggerang Selatan \\ Email: fathurrahman.djamil@uinjkt.ac.id
}

\begin{abstract}
Looking for the Progressive with Local Wisdom Islamic Law: Socio-Cultural and Maqashid al Syariah Approach. Islamic law is a law that will be compatible at all the times and places (shalihun likuli zaman wa makan). However, sometimes in the application there are also problems that are difficult to compromise if not using a new approach. The use of socio-cultural approach and ushul fiqh approach, especially maqashid alsyariahs in studying shariah is needed especially to get an appreciative syariah format to the traditions and culture of Muslim society in all parts of the world. Socio-historical approach that observed in the historical development of the science of jurisprudence and usul fiqh, has been applied by the jurists.
\end{abstract}

Keywords: Islamic Law, Local Wisdom, Cultural Social, Maqashid Syariah

Abstrak: $\quad$ Mencari Format Hukum Islam yang Progresif Berkearifan Lokal: Pendekatan Socio-Cultural dan Maqashid Al Syariah. Hukum Islam adalah hukum yang akan senantiasa cocok dengan segala perkembangan zaman dan tempat (shalihun likulli zaman wa makan). Hanya saja, terkadang dalam penerapannya terdapat juga masalah-masalah yang sulit dikompromikikan jika tidak menggunakan pendekatan baru. Penggunaan pendekatan sosiocultural dan pendekatan ushul fiqh, khususnya Maqashid al-Syariah dalam mengkaji syariah sangat dibutuhkan terutama untuk mendapatkan format syariah yang apresiatif terhadap tradisi dan budaya masyarakat muslim di seluruh belahan dunia. Pendekatan socio-historis kalau dicermati dalam sejarah perkembangan ilmu fikih dan ushul fikih, sudah dilakukan oleh para fukaha.

Kata kunci: Hukum Islam, Kearifan Lokal, Sosial kultural, Maqashid Syariah

\section{Pendahuluan}

Relasi antara Islam sebagai agama dengan adat dan budaya sangat jelas dalam kajian antropologi agama. Dalam perspektif ini diyakini, 
bahwa agama merupakan penjelmaan dari sistem budaya. ${ }^{1}$ Berdasarkan teori ini, Islam sebagai agama samawi dianggap sebagai penjelmaan dari sistem budaya suatu masyarakat muslim. Tesis ini kemudian dikembangkan pada aspek-aspek ajaran Islam, termasuk aspek hukumnya. Para sarjana antropolgi dan sosiologi mendekati hukum Islam sebagai institusi kebudayaan muslim. Saat ini pengkajian hukum dengan pendekatan sosiologis dan antropologis sudah dikembangkan oleh para ahli hukum Islam yang peduli terhadap nasib syariah. Dalam pandangan mereka, jika syariah tidak didekati secara sosio-historis, maka yang terjadi adalah pembakuan terhadap norma syariah yang yang sejatinya bersifat dinamis dan mengakomodasi perubahan masyarakat ${ }^{2}$. Akibatnya, sulit dibedakan mana yang bersifat universal dan berlaku umum dan mana pula yang lokal dan berlaku untuk masyarakat tertentu.

Secara sosiologis dapat dikatakan, bahwa norma-norma hukum tidak dapat diwujudkan tanpa mempunyai landasan norma sosial. Sementara itu, norma-norma sosial, sesuai dengan sifatnya, tidak statis, melainkan dinamis dan berkembang dari satu masyarakat ke masyarakat lainnya. Konsekwensinya, norma syariah, termasuk di dalamnya fikih, harus senantiasa berinteraksi dengan norma, sistem dan struktur sosial yang selalu berubah. ${ }^{3}$ Pertanyaan yang mendasar, dalam kaitan ini, adalah: Bisakah syariah diperbaharui berdasarkan analisis konsep hukum, yang diperkaya dengan perspektif sosiologis dan antar kebudayaan?

Pendekatan legal normatif semata-mata dianggap oleh sebagian pihak sebagai langkah konservatif yang kaku. Bahkan mereka lebih jauh menyatakan, jika Islam ingin diterima oleh masyarakat modern, dengan ragam tradisi dan budayanya, maka pendekatan fikih sebaiknya ditinggalkan. ${ }^{4}$ Itulah sebabnya para pemikir muslim bercorak 'ashraniy (modernis) lebih memilih pendekatan lain, selain fikih. Tumbuh suburnnya pendekatan sosiologis dan historis terhadap syariah, merupakan upaya yang sangat strategis, sehingga Islam yang berwatak universal itu

${ }^{1}$ Bassam Tibbi, Islam and Cultural Accommodation of Social Change, (San Prancisco: Westview Pres, 1991), h. 1.

${ }^{2}$ Aziz Al-Azmeh (Ed.), Islamic Law: Social and Historical Contexts, 1988, h. viii

3 Mohammad Atho Mudzhar, Islam and Islamic Law in Indonesia: A Socio-Historical Approach, (Jakarta: Ministry of Religious Affairs Republic of Indonesia, 2003), h. 93

${ }^{4}$ Jorgen S. Nielson, Kata Pengantar dalam Tariq Ramadan, Dialog Teologi Islam-Barat, Pergumulan Muslim Eropa, terj Abdullah Ali, (Bandung: Mizan,2002), h. 17. 
dapat hidup subur berdampingan dengan tradisi dan budaya masyarakat muslim dalam letak geografis yang berbeda.

Makalah ini bermaksud melihat kemungkinan penggunaan pendekatan sosio-cultural dan pendekatan ushul fiqh, khususnya maqashid al-syariahs dalam mengkaji syariah. Melalui pendektan ini diharapkan akan ditemukan format syariah yang apresiatif terhadap tradisi dan budaya masyarakat muslim di seluruh belahan dunia, termasuk di Indonesiai.

\section{Dinamika Syariah Dalam Lintasan Sejarah}

Syariah sebagai suatu tatanan dan pranata sosial sering diidentikkan dengan aturan hukum praktis, yang berkarakter universal, dinamis dan fleksibel. Universalitas syariah merupakan bagian tak terpisahkan dari ciri kesemestaan ajaran Islam yang diekspresikan oleh Al-Qur'an sebagai rahmatan li al'alamin. Namun, karena syariah bersifat praktis, maka sudah dipastikan bahwa pengaruh masyarakat yang menjadi subjek dan sekaligus objek syariah menjadi salah satu variabel yang berpengaruh terhadap ketentuan dan norma syariah yang diyakini sebagai suatu yang bersifat divine atau ilahiyat, sebagai variabel yang independen.

Sejak awal keberadaannya, syariah telah menampilkan dirinya sesuai dengan perkembangan dan dinamika masyarakat. Syariah yang dibawa oleh para nabi mencerminkan keberadaan dari masyarakat yang hidup pada zamannya. Keadaan ini berbeda dengan agama (al-Din atau alMillah) yang bersifat konstan dan permanen, tidak mengalami perubahan. Atas kenyataan inilah muncul adagium "al-Dinu Wahid wa al-Syarai Mukhtalifah". Al-Qur'an mengillustrasikan keberadaan syariat yang dibawa oleh Nabi Muhammad merupakan syariat yang dalam batas tertentu membenarkan apa yang telah disyariatkan kepada para nabi sebelumnnya, sekaligus sebagai syariat yang menyempurnakan syariat sebelumnya. ${ }^{5}$

Sikap Al-Quran yang membenarkan syariat sebelumnya terlihat secara jelas, ketika Nabi Muhammad, sebagai penerima Al-Quran berada di Makah. Pada periode ini Muhammad bertugas sebagai Nabi dan Rasul atau sebagai kepala agama, bukan sebagai kepala negara atau

${ }^{5}$ QS. Ali Imran[3:3] yang artinya,"Dia menurunkan al-Kitab (al-Qur'an) kepadamu dengan sebenarnya;membenarkan kitab yang telah diturunkan sebelumnya dan menurunkan Taurat dan Injil." Lihat pula QS. Al-Maidah[5:48]. 
kepala pemerintahan. Tentu sebagai kepala agama beliau berusaha untuk menyampaikan (tabligh) apa yang menjadi inti utama ajaran tauhid, sebagaimana misi para nabi sebelumnya. Karena itu, format keagamaan yang dibangun dan dikembangkan oleh beliau lebih banyak membenarkan dan melanjutkan apa yang telah diajarkan dalam kitab suci samawi sebelumnya. Sampai periode ini syariah lebih diarahkan pada aspek akidah dan keluhuran moral, dan belum merambah kepada upaya law enforcement, sebagaimana akan terlihat pada periode Madinah.

Sementara itu, fungsi penyempurna yang dilekatkan pada al-Qur'an mulai tampak kepermukaan, ketika wahyu Tuhan berinteraksi dengan kondisi objektif masyarakat Madinah yang bersifat plural, dan karena itu memerlukan aturan yang bersifat lebih praktis dan pragmatis, dan merupakan implementasi dari norma moral yang bersifat universal yang telah dikembangkan di Makah. Itulah sebabnya, mengapa keuniversalan norma dalam syariah Mekah tereduksi dengan kesetempatan dari masyarakat Madinah. Belum lagi, kalau dicermati lebih lanjut, bahwa Muhammad, sudah mempunyai tugas dan fungsi yang lebih banyak, yakni sebagai kepala agama, kepala negara dan kepala pemerintahan. Multi fungsi ini, langsung atau tidak langsung, berpengaruh terhadap norma syariah yang merupakan ciri dari periode ini. Dari kenyataan inilah ahli hukum Islam merumuskan teori "Tasharrufat al-Rasul". ${ }^{6}$ Teori ini berusaha memisahkan fungsi-fungsi yang ada pada Nabi Muhammad, sehingga bisa dianalisis secara proporsional kapasitas dan implikasinya terhadap pelaksanaan syariah dikemudian hari.

Sejarah mencatat, bahwa syariah yang dijadikan acuan oleh umat Islam pasca Nabi Muhammad adalah syariah yang dikembangkan di Madinah. Struktur masyarakat Madinah dan kondisi sosial budayanya menjadi bagian yang tak terpisahkan dari norma syariah yang diacu oleh umat islam dalam lintasan sejarahnya. ${ }^{7}$ Keterikatan terhadap norma syariah Madinah merupakan komitmen umat Islam pasca Nabi Muhammad. Namun demikian, setelah Islam dianut oleh umat yang berlatar belakang budaya dan adat istiadat yang berbeda dengan masyarakat Arab, mulai terjadi pemahaman syariah dalam versi masyarakat yang bersangkutan. Hal

${ }^{6}$ Al-Qarafi, al-Furuq, (Mekah: Dar Ihya al-Kutub al-Arabiyyah, tth), Juz I, h 205-209. Lihat Juga Mahmud Syaltut, Al-Islam Aqidah wa Syariah, (Tt: Dar al-Qalam, tth.), h. 508-511.

7 Joseph Schacht, An Introduction To Islamic Law, Clarendon Press, Oxford, 1964, 199 
itu sudah terjadi ketika Umar Ibn Khaththab menjadi kepala pemerintahan yang wilayahnya sudah mencakup wilayah di luar jazirah Arabia. Tidak jarang kebijakan publik beliau berbeda dengan apa yang ditetapkan atau dilaksanakan oleh Abu Bakar bahkan oleh Nabi sendiri. ${ }^{8}$

Asimilasi dan akulturasi kebudayaan non Arab dengan syariah Madinah lebih banyak terlihat ketika pusat pemerintahan Bani Umayyah ditetapkan di Damaskus (Siria) yang merupakan tempat pertemuan peradaban Timur-Arab dan non arab. Kendatipun kebijakan utama pemerintahan Bani Umayyah difokuskan pada Arabisasi bahasa administrasi, tetapi dalam bidang pemikiran hukum ditemukan fakta, bahwa masyarakat yang multi etnis dan budaya serta peradabannya banyak berpengaruh terhadap syariah lokal pada periode ini. Munculnya nama Abu Hanifah ${ }^{9}$ pada masa dinasti ini merupakan bukti kebenaran pernyataan di atas. Begitu juga munculnya institusi hukum baru, yang diduga berasal dari tradisi masyarakat non Arab, dapat dijadikan bukti betapa pengaruh kebudayaan non Arab kepada institusi syariah. Misalnya, lembaga wilayat al-mazhalim, yang muncul pada akhir pemerintahan Bani Umayyah diduga berasal dari tradisi masyarakat non Arab.

Puncak asimilasi dan interaksi antara tradisi arab dan budaya non arab terjadi pada masa pemerintahan Bani Abbas. Masuknya orang-orang Persia ke dalam pemerintahan Abbasiah meniscayakan terjadinya perubahan cara berfikir dan cara pandang terhadap syariah yang diasumsikan berbasis tradisi, budaya dan struktur masyarakat arab menjadi syariah yang menghargai tradisi intelektual yang terbuka, seperti yang berkembang di Persia. Kitab-kitab ushul fikih, yang merupakan teori yang berkaitan dengan implementasi syariah, mulai terbuka untuk mengakomodasi wacana dalam bidang teologi dan filsafat. Tentu hal ini hanya dimungkinkan apabila

${ }^{8}$ Sebagai contoh, pada peristiwa penaklukan Irak dan Syam, Umar Ibn Khaththab tidak membagikan tanah rampasan perang sebagaimana ketentuan dalam al-Quran surat al-Anfal [8:4]. Umar menggantinya dengan kewajiban membayar uang upeti dan pajak kepala bagi seluruh warga Negara di daerah taklukan dan hal itu menjadi harta fai bagi kaum muslimin. Semua itu diperuntukkan bagi pembiayaan tentara di pos-pos penjagaan di beberapa wilayah Islam. Lihat: Khudhari Bek, Tarikh al-Tasyri' al-Islami, terj. M. Zuhri, (Semarang: Darul Ihya, tth), h. 268-271.

${ }^{9}$ Beliau lahir di Kufah tahun $81 \mathrm{H}(700 \mathrm{M})$ dan wafat pada tahun $150 \mathrm{H}(767 \mathrm{M})$. Beliau lahir pada masa khalifah Umayyah berkuasa yaitu masa berkuasanya Abdul Malik bin Marwan (685705M) khalifah kelima Bani Umayyah, dan hidup sampai berkuasanya Bani Abbas tahun 150 H (767 M) pada saat berkuasanya Abu Ja’far al-Manshur. Lihat: Cyril Classe, Ensiklopedi Islam (Ringkas), terj. Ghufran A. Mas'udi, (Jakarta: PT. Raja Grafindo Persada, 1996), Ed. I, Cet. I, h. 8. 
kebijakan pemerintahan Abasiah membuka peluang untuk itu. Begitu pula halnya dengan kitab fikih yang muncul pada periode ini. Kitab al-Ahkam al-Sulthaniyyah ${ }^{10}$ dan Kitab al-Kharraj ${ }^{11}$ dapat dijadikan contoh betapa syariah lokal sudah menampilkan wujudnya.

Setelah pemerintahan umat Islam berada di tangan Bani Usman, persentuhan antara syariah dengan budaya lokal menjadi semakin jelas relasinya. Ketika masyarakat muslim yang berada di wilayah Turki Usmani belum bersentuhan dengan tradisi dan budaya "Eropa Modern", implementasi syariah masih berbasis tradisi "Arab dan Sekitarnya". Munculnya kodifikasi hukum di bidang muamalat, Majallat Ahkam alAdliyat, yang berorientasi pada mazhab hanafi, merupakan bukti relasi syariah dengan tradisi dan budaya Arab dan sekitarnya. Namun, setelah terjadi interaksi dengan tradisi dan budaya Eropa modern, mulai muncul konsep dan gagasan untuk mengakomodasi tradisi dan budaya masyarakat Eropa modern. Akhirnya turki usmani dibawa kepada pemikiran sekuler oleh Kemal Attaturk.

\section{Upaya Melokalkan Syariah}

Berdasarkan kenyataan sejarah di atas, secara akademik mulai dimunculkan pertanyaan: apakah norma syariah periode Madinah, yang diyakini sebagai wahyu Tuhan, dapat diubah atau disesuaikan dengan tuntutan tradisi dan kebudayaan masyarakat non Arab-Madinah? Adakah pertentangan diantara keduannya?

Guna menjawab persoalan itu, kelihatannya berbagai cara dan upaya dilakukan oleh para ahli hukum Islam, mulai dari yang terkesan sekuler sampai pada yang terkesan fundamentalis. Salah satu caranya adalah dengan melihat kembali norma syariah yang genuine, sesuai dengan kondisi objektif masyarakat ketika syariah dibuat. Dalam kaitan ini, Khalid Masud ${ }^{12}$ menyatakan, bahwa sebab terjadinya ketegangan syariah dengan masyarakat

${ }^{10}$ Beliau mengemukakan konsep pengangkatan kepala Negara atau kepala pemerintahan melalui dua cara: pemilihan dan pengangkatan. Kedua cara ini sudah menjadi konvensi dalam pemerintahan umat Islam. Lihat Al-Mawardi, al-Ahkam al-Sulthaniyah, Dar al-Fikr, Beirut, tth., h. 6

11 Kitab ini dipersembahkan oleh Abu Yusuf kepada Khalifah Harun Al-Rasyid yang merupakan respon terhadap kebutuhan system fiscal dan moneter pada masanya. Lihat Kitab AlKharaj, Dar al-Marifath, Beirut, tth. h. 3.

12 Muhammad Khalid Masud, Islamic Legal Philosophy: A Study of Abu Ishaq al-Shathibi's Life and Thought, (Islamic Research Institute, Islamabad, 1984), h. 3. 
yang beragam adalah pengabaian ahli hukum Islam terhadap pentingnya landasan normatif dari syariah itu sendiri dan kurang digunakannya berbagai pendekatan terhadap penelitian hukum Islam.

Pernyataan di atas berbeda dengan tesis sebagian ahli hukum Islam yang melihat bahwa syariah normatif dianggap sebagai akar masalah munculnya kesulitan syariah dalam menghadapi berbagai persoalan hukum kontemporer, sebagai konsekwensi terjadinya kemajuan ilmu pengetahuan dan teknologi di satu sisi dan keragaman adat istiadat dan budaya masyarakat muslim di sisi yang lain. Mereka, secara apriori berkesimpulan, bahwa norma syariah yang tertulis dalam al-Qur'an dan Hadis sudah out of date, dan karena itu harus ditinggalkan sama sekali dan dicarikan alternatif hukum lain yang dianggap sesuai dengan kondisi masyarakat modern. Para pemikir dari Turki, seperti Zia Gokalf ${ }^{13}$ dan Kemal Attaturk termasuk kelompok ini. Begitu pula Pemikir dari Siria, seperti Muhammad Charfi dan Siddiq al-Azam, mempunyai pendapat serupa.

Di pihak lain kelompok fundamentalis atau tradisionalis berkeyakinan, bahwa adat dan budaya yang bertentangan dengan syariah merupakan penyimpangan dari syariah. Mereka berpendapat bahwa syariah merupakan aturan yang mengikat bagi seluruh umat Islam, semata-mata karena ia berasal dari Tuhan. Dalam pandangan mereka, kedaulatan Tuhan sama dengan kedaulatan syariah. Sayid Qutb termasuk kelompok ini.

Upaya apa yang harus dilakukan untuk memahami bahwa syariah, sebagaiamana agama Islam senantiasa sesuai dengan situasi dan kondisi masyarakat yang beragam, baik budaya, adat istiadat dan bahkan peradabannya.? Telah banyak upaya yang dilakukan oleh para ahli hukum Islam dan pemikir muslim untuk menjembatani antara kelompok sekularis dan islamis. Secara garis besar upaya itu dapat dikelompokkan menjadi dua: kelompok yang masih berorientasi pada keuniversalan syariah normatif yang dapat memberikan keragaman dalam syariah historis (fikih), dan kelompok yang melihat bahwa syariah normatif sudah dengan sendirinya bersifat universal dan dapat dijadikan sebagai landasan penyelesaian persoalan hukum Islam dalam lintasan sejarah dan keragaman budaya. Atau dalam ungkapan lain, Hallaq membedakan syariah menjadi

${ }^{13}$ Lihat Niyazi Berkes, Turkish Nationalism and Western Civilization: Selected Essays of Ziya Gokalp, Columbia University Press, New York, 1959, h. 1 
dua kelompok, yaitu syariah sebagai "sumber hukum" dan syariah sebagai "substansi hukum" ${ }^{14}$ Dalam kajian ini penulis membedakannya menjadi dua kelompok, yaitu kelompok "legal normatif" dan kelompok "legal substantif".

Kelompok pertama mempunyai tesis bahwa syariah normatif sangat terbatas jumlahnya, sementara persoalan-persoalan hukum dan kemanusiaan tidak pernah akan berakhir dan tidak pernah ada batasnya (al-Nushus Mutanahiyah wa al-Waqai Ghairu Mutanahiyah). Karena itu, Syariah yang merupakan hukum Tuhan harus dijaga supaya tetap berada pada posisi ilahiatnya, dengan cara melaksanakan secara "harfiah" apa yang tertulis dalam teks suci itu, sementara perkembangan masyarakat dapat diselesaikan melalui jalur pemahaman terhadap teks suci, sesuai dengan perkembangan tradisi masyarakat muslim. Dalam konteks ini dibedakan antara syariah di satu sisi dan fikih di sisi yang lain.

Problem yang muncul dari cara berfikir kelompok ini adalah, apakah seluruh ayat al-Quran dapat dijadikan sebagai sumber syariah normatif. Perdebatan tentang masalah ini tidak pernah berakhir. Adanya kategori ayat ahkam dan bukan ayat ahkam merupakan simplifikasi dari penyelesaian persoalan tersebut. Kalau solusi ini dianggap tepat, maka persoalan berikutnya adalah berkaitan dengan penafsiran ayat-ayat hukum dimaksud. Apakah teks suci yang berkaitan dengan hukum bersifat interpretable? Wacana qathiy dan dzanniy tampaknya merupakan persoalan yang menarik. Meskipun perkembangan terakhir mengarah kepada kesimpulan, bahwa ayat-ayat al-Quran bersifat multi tafsir, dan karena itu tidak ada lagi ayat yang bersifat qathiy. ${ }^{15}$ Konsekwensinya hukum Islam didominasi oleh fikih, bukan syariah, yang tentu bersifat relatif. Relatifitas fikih itu direlasikan kepada siapa yang menafsirkan syariah, dimana syariah itu ditafsirkan dan kapan syariah itu ditafsirkan. Dalam konteks ini tentu tradisi, budaya dan peradaban ikut terlibat dalam memahami syariah normatif. Dalam level ini diyakini bahwa syariah yang bersumber dari wahyu Tuhan bersifat multi interpretasi atau meminjam istilah Hart, bahwa teks suci harus diasumsikan sebagai jaringan yang terbuka (open texture). ${ }^{16}$ Itulah sebabnya

${ }^{14}$ Wael B. Hallaq, A. History of Islamic Legal Theories. An Introduction to Sunni Ushul Fiqh, (Cambridge: Cambridge University Press, 1997), h. 166.

${ }^{15}$ M. Quraish Shihab, Membumikan al-Quran, (Bandung:Mizan, 1997), Cet. XIV, h. 138.

${ }^{16}$ Bassam Tibbi, Islam and Cultural Accommodation of Social Change, h. 63 
fikih dapat dianggap sebagai syariah historis. Keragaman dalam syariah jenis ini merupakan keniscayaan dan tidak dapat dihindari.

Sebenarnya kelompok legal normatif telah mengakui, bahwa dalam sumber syariah normatif terkandung unsur-unsur sosial budaya yang melatar belakangi turunnya ayat hukum. Diasumsikan, bahwa setiap ayat hukum mempunyai latar belakang atau sebab mengapa ayat itu diturunkan (sabab nuzul). Artinya, bahwa ayat al-Quran yang berkaitan dengan syariah tidak a sosial dan tidak a historis.

Kelompok kedua, yang berpendapat bahwa syariah normatif dengan sendirinya dapat dijadikan acuan oleh setiap masyarakat dalam keragaman tradisi dan budaya, berusaha memahami norma syariah yang ada pada periode Madinah sebagai norma dasar yang jiwanya harus digali dan diimplementasikan dalam kehidupan umat Islam, sesuai dengan kondisi yang beragam. Dalam pencariannya, mereka memfokuskan pada dua hal, pertama menjadikan norma syariah sebagai nilai moral dan etika sosial, dan kedua, mencari akar kemaslahatan yang melandasi norma syariah Madinah.

Dalam kaitannya dengan fokus kajian yang berorientasi pada legalsubstantif, diyakini oleh sebagian pemikir muslim, bahwa syariah bukan hanya sumber hukum semata, tetapi lebih dari itu merupakan cerminan dari sumber nilai moral dan etika sosial. Fazlul Rahman, misalnya berpendapat bahwa ketentuan atau norma yang terdapat dalam syariah harus difahami dalam konteks moral dan etika masyarakat yang bersifat universal. Keadilan, kebebasan dan persamaan diyakini sebagai cita-cita syariah yang harus menjadi landasan dalam menetapkan hukum. Kalaupun al-Quran secara partikular aturan tentang masalah muamalah, baik perdata maupun pidana, hal itu tidak boleh difahami sebatas yang tertulis dalam teks, tetapi harus dilihat secara cerdas cita-cita syariah yang terkandung di dalamnya. Karena itu, ketika masyarakat muslim telah berubah dan berbeda dengan keadaan masyarakat muslim awal, maka perubahan ketentuan hukum merupakan suatu keniscayaan. ${ }^{17}$ Sedangkan fokus kajian kedua dari legal-substantif diarahkan pada pencarian tujuan utama disyariatkan norma syariah. Simpul dari tujuan itu diarahkan pada kemaslahatan yang dijadikan sebagai tujuan

${ }^{17}$ Fazlul Rahman, Islam, (Chicago: University of Chicago Press, 1979), h. 115. Lihat pula: Fazlul Rahman, Islamic Methodology in History, (Islamabad:Islamic Research Institut, 1984), h.1. 
utama. Khalid Masud, misalnya meyakini bahwa kemaslahatan, yang dicerminkan dalam "panca jiwa" syariah (al-Kulliyat al-Khams), merupakan landasan norma syariah, yang dengan sendirinya dapat diacu oleh setiap masyarakat muslim dengan keragaman tradisi, budaya dan peradabannya. ${ }^{18}$ Kelihatannya kedua fokus kajian di atas mempunyai kesamaan strategi dalam upaya mencari akar tradisi dan budaya dalam syariah. Nilai-nilai moral dan etik yang universal dan panca jiwa yang universal, hakikatnya merupakan inti dari gagasan mereka.

\section{Syariah yang Berbasis Keragaman Budaya}

Berdasarkan uraian di atas dapat difahami, bahwa norma syariah tidak dapat dipisahkan dari norma sosial. Sejalan atau tidaknya norma syariah dengan norma sosial ditentukan oleh struktur masyarakat yang merupakan dependent variabel dari norma syariah. Karena itu, keragaman budaya dan tradisi masyarakat meniscayakan adanya keragaman norma syariah. Sejatinya, cita moral dan etik syariah pada periode Madinah, sebagaimana terdapat dalam al-Quran, menuntut diimplementasikannya kebebasan, persamaan dan keadilan. Akan tetapi, struktur masyarakat dan munculnya stratifikasi sosial dalam masyarakat muslim, dari masa ke masa, atas dasar kedudukan, jenis kelamin dan agama, tidak memungkinkan terlaksanannya cita-cita dimaksud. Konsekwensi lebih jauh adalah, dibawah pengaruh norma sosial, setiap periode, hukum Islam mengembangkan struktur hukum. Ketika norma sosial itu diasimilasikan ke dalam norma syariah, maka norma sosial itu dianggap abadi dan ilahiyat, sebagaimana nilai-nilai universal syariah yang diwahyukan.

Relasi yang beragam antara syariah dengan budaya masyarakat muslim, dibahas secara mendalam oleh Tariq Ramadan. ${ }^{19}$ Beliau berpendapat, bahwa hukum dan yurisprudensi harus mempertimbangkan sumber dan konteks sosial, budaya, politik dan ekonomi. Implementasi hukum bersifat luwes dan dapat berubah, sesuai dengan kontek waktu dan letak geografis. Tentu pendapat ini bukanlah merupakan sesuatu yang baru, apabila dihubungkan

${ }^{18}$ Khalid Masud, Islamic Legal Philosophy: A Study of Abu Ishaq Al-Shathibis Life and Thought, (Islamabad:Islamic Research Institute, 1977), h 221 . Lihat Juga tulisan nya "Pencarian Landasan Normatif Syariah Para Ahli Hukum Muslim,", dalam Dick van der Meij, (Ed.) Dinamika Kontemporer Dalam Masyarakat Islam, INIS, Jakarta, h. 9.

${ }^{19}$ Tariq Ramadan, Teologi Dialog Islam-Barat, (Bandung: Mizan, 2002), Cet I, h. 67-69. 
dengan pendapat para orientalis yang secara khusus meneliti hukum Islam dengan pendekatan sosiologis dan historis. Tidak heran, kalau banyak umat Islam yang kurang berkenan dengan gagasan ini, dengan berbagai macam alasan. Salah satunya karena penedekatan ini dikembangkan oleh para orientalis, yang diduga berusaha untuk memisahkan umat Islam dari sumber aslinya, al-Quran dan al-Sunnah.

Sebenarnya gagasan saling keterpengaruhan syariah dengan adat dan budaya masyarakat muslim yang beragam, tidak hanya dikemukakan oleh pemikir hukum Islam kontemporer termasuk orientalis, seperti yang dijelaskan di atas, tetapi telah terdapat dalam khazanah pemikiran umat Islam sebelumnya. Salah seorang pemikir muslim yang apresiatif terhadap budaya dan adat setempat adalah Abu Ishak Al-Syathibi. Karyanya yang monumental dalam teori hukum Islam, al-Muwafaqat $f i$ Ushul al-Syariah (Beberapa persesuaian dalam dasar-dasar Syariah), merupakan bukti bahwa beliau berusaha untuk mempertemukan antara syariah dengan tradisi.

Al-Syathibi membuktikan bahwa faktor adat dan praktek sosial berpengaruh pada pemahaman norma syariah. Beliau mendeduksi bahwa syariah didasarkan pada kemaslahatan, yang dibedakan menjadi kemaslahatan yang bersifat dlaruriyat (primer) hajiyat (sekunder) dan tahsiniyat (tersier) ${ }^{20}$ Baginya, kemaslahatan dalam lingkaran yang pertama bersifat universal dan diakui oleh semua bangsa dan agama. Kemaslahatan dalam lingkaran kedua adalah hukum dan praktek sosial yang diasimiliasikan ke dalam syariah, dengan memperhatikan kemaslahatan umum, seperti masalah qiradl atau mudlarabah. Sedangkan lingkaran ketiga dari kemaslahatan adalah hukum yang diisi oleh unsur-unsur praktek sosial yang lebih halus, seperti kesopanan, kebersihan dan norma-norma budaya dan adat lainnnya. Menurut Al-Syathibi, Syariah mengadopsi unsur-unsur ini, sebab semuanya dianggap mencerminkan kepatutan dan pilihanpilihan budaya dalam suatu masyarakat. ${ }^{21}$ Ia memberikan illustrasi sebagai berikut. Keluar rumah tanpa menutup kepala di Timur dianggap sebuah pelanggaran terhadap kesopanan, sementara di barat tidak demikian, bahkan bisa sebaliknya. $^{22}$

${ }^{20}$ Abi Ishaq al-Syathibi, al-Muwafaqat $f$ Ushul al-Syariah, (Beirut: Dar al-Kutub al-Ilmiyyah, tth), Jilid II, h. 7.

${ }^{21}$ Abi Ishaq al-Syathibi, al-Muwafaqat fi Ushul al-Syariah,h. 216.

${ }^{22}$ Abi Ishaq al-Syathibi, al-Muwafaqat fi Ushul al-Syariah. h. 216 
Begitu besarnya perhatian Al-Syathibi terhadap adat dan budaya masyarakat, ia menyebut bahkan mengidentikan muamalat dengan adat. Karena itu, menurutnya, adat dapat menentukan hal yang baik atau buruk. Bahkan syariah, dalam batas tertentu mengesahkan hasilnya. Lebih lanjut, baginya konsep mashlahat berkait erat dengan norma baik dan buruk dalam masyarakat. Mana yang lebih dominan diantaranya diterima syariah. ${ }^{23}$ Kaitan dengan pendekatan historis yang ditawarkan oleh pemikir kontemporer, Al-Syathibi mengkaji norma syariah dalam alQuran dengan menempatkannya dalam kontek sejarah. Dia menemukan relasi antara norma syariah dalam al-Quran dengan praktek lokal. Dia memberi contoh, norma hukum yang ada di Mekah merepresentasikan norma hukum yang universal, norma dasar dan merupakan tujuan utama syariat Islam. Sementra norma hukum yang ada di Madinah merupakan hukum yang nyata dan lebih bersifat operasional, sekaligus penerapan hukum yang bersifat lokal, merupakan rincian dari dari norma hukum Makah yang universal. Melalui pendekatan historis itu, dia berkesimpulan bahwa apabila ahli hukum Islam mengabaikan prinsip-prinsip universal ayat-ayat Makiyah dan mengabaikan metode induktif, maka mereka akan berhadapan dengan masalah yang serius berhadapan dengan tradisi dan kebudayaan baru.

\section{Penutup}

Mencari format syariah lintas budaya merupakan wacana yang sudah lama dibincangkan oleh para ahli hukum Islam. Umumnya mereka berpendapat, bahwa syariah yang terdapat dalam Al-Quran dan al-Sunnah harus diifahami sebagai norma etika dan moral yang bersifat universal dan berlaku untuk semua masyarakat, melintasi suku, bangsa, budaya, adat istiadat bahkan agama sekalipun. Itulah, setidaknya, yang dapat ditemukan dalam teori al-Kulliyat al-Khams atau teori etika sosial-hukum dari kalangan penganut legal substantif. Melalui teori dan pendekatan yang beragam ini dapat direkonstruksi pemikiran hukum Islam yang berbasis budaya masyarakat muslim, dimana pun mereka berada.

Memang harus diakui, bahwa pendekatan socio-historis terhadap syariah merupakan sesuatu yang dianggap asing oleh kebanyakan ahli

\footnotetext{
${ }^{23}$ Abi Ishaq al-Syathibi, al-Muwafaqat fi Ushul al-Syariah h. 232-235
} 
hukum Islam. Padahal, kalau dicermati dalam sejarah perkembangan ilmu fikih dan ushul fikih, ternyata apresiasi fukaha terhadap tradisi dan budaya masyarakat muslim tidak dapat dibantah. Adagium: "Taghayyur al-fatwa bi taghayyur al-azminah wa al-amkinah wa al-awaid", merupakan bukti dari apresiasi itu. Teori 'urf, baik sebagai sumber atau metode penetapan hukum merupakan bagian dari kepedulian fukaha terhadap keragaman budaya masyarakat muslim, dari satu masa ke masa yang lainnya. Persoalan norma baik dan buruk, maslahat dan mafsadat tidak bisa terlepas dari tradisi masyarakat.

\section{Pustaka Acuan}

al-Azmeh, Aziz, Islamic Law: Social and Historical Context, 1988.

Classe, Cyril. Ensiklopedi Islam (Ringkas), terj. Ghufran A. Mas'udi, Jakarta: PT. Raja Grafindo Persada, 1996,, Ed. I, Cet. I.

Coulsen, Noel J. Conflicts Andtensionsin Islamic Jurisprudense, Chicago \& London: The University of Chicagho Press.1969.

Hallaq, Wael B. A. History of Islamic Legal Theories. An Introduction to Sunni Ushul Figh, Melbourne: Cambridge University Press, 1997.

Khalid Masud, Muhammad, Islamic Legal Philosophy: A Study of Abu Ishaq Al-Shathibis Life and Thought, (Islamabad:Islamic Research Institute, 1977.

Khudhari, Bek, Tarikh al-Tasyri al-Islami, terj. M. Zuhri, Semarang: Darul Ihya, tth. ,"Pencarian Landasan Normatif Syariah Para Ahli Hukum Muslim,", dalam Dick van der Meij, (Ed.) Dinamika Kontemporer Dalam Masyarakat Islam, INIS, Jakarta.

Mudzhar, Mohammad Atho . Islam and Islamic Law in Indonesia: A SocioHistorical Approach, Jakarta: Ministry of Religious Affairs Republic of Indonesia, 2003.

An-Na'im, Abdullah Ahmed. Toward an Islamic Reformation, New York: Syracuse University Press, 1996.

Nielson, Jorgen S. Kata Pengantar dalam Tariq Ramadan, Dialog Teologi Islam-Barat, Pergumulan Muslim Eropa, terj Abdullah Ali, Bandung: Mizan,2002.

al-Qarafi, al-Furuq, Mekah: Dar Ihya al-Kutub al-Arabiyyah, tth, Juz 
al-Qardhawi, Yusuf. Al-Ijtihad fi al-Syariat al-Islamiyah, Kuwait: Dar alQalam, Cet I, 1985M/1406H.

Rahim, Abdul, The Principles of Muhammadan Jurisprudence, London: Luzac \&Co, 1911.

Rahman, Fazlul. Islam, Chicago: University of Chicago Press, 1979. , Islamic Methodology in History, Islamabad:Islamic Research Institut, 1984.

Ramadan, Tariq .Teologi Dialog Islam-Barat, Bandung: Mizan, 2002, Cet I.

Shihab, M. Quraish, Membumikan al-Quran, Bandung:Mizan, 1997, Cet. XIV.

al-Syathibi, Abi Ishaq . al-Muwafaqat fi Ushul al-Syariah, Beirut: Dar alKutub al-Ilmiyyah, tth, Jilid II.

Syaltut, Mahmud, Al-Islam Aqidah wa Syariah, Tt: Dar al-Qalam, th.

Tibbi, Bassam. Islam and Cultural Accommodation of Social Change, San Prancisco: Westview Pres, 1991. 